\title{
A Field Survey of Crop management Practices and Distribution OF ALS RESISTANT Euphorbia heterophylla IN Two STATES IN SOUTHERN BRAZIL ${ }^{1}$
}

\author{
Avaliação das Práticas de Manejo das Lavouras e da Distribuição Geográfica de Euphorbia \\ heterophylla Resistente aos Inibidores de ALS em Dois Estados do Sul do Brasil
}

\author{
VIDAL, R.A. ${ }^{2}$, WINKLER, L.M. ${ }^{3}$, HERNANDES, G.C. ${ }^{4}$, FLECK, N.G. ${ }^{2}$, MEROTTO JR., A. ${ }^{2}$ e \\ TREZZI, M.M. ${ }^{5}$
}

\begin{abstract}
Herbicide resistance was reported in Brazil almost ten years ago. One of the main weeds with herbicide resistance is wild poinsettia (Euphorbia heterophylla). This work evaluates the distribution of ALS-resistant E. heterophylla in two states in southern Brazil and determines the major contributing management causes for weed resistance selection in the area. E. heterophylla seeds from 148 sites located in Paraná and Rio Grande do Sul were sampled during 2001 and 2002. Farmers provided specific site data for weed control, tillage system, crop rotation and harvesting operations during previous years. ALS resistant E. heterophylla biotypes were found widely distributed in the survey area. Data analysis suggests seed dissemination is unlikely to explain the widespread distribution of resistance. The most probable factor for the selection of the resistant E. heterophylla is the persistent high use of ALS-inhibiting herbicides over time. Indirect evidence is presented demonstrating the need to educate legislators and farmers about the importance of herbicide mixtures as a strategy to prevent herbicide resistance.
\end{abstract}

Key words: imazethapyr, wild poinsettia, herbicide mixtures.

\begin{abstract}
RESUMO - A resistência aos herbicidas foi relatada no Brasil há quase uma década. Uma das principais plantas daninhas com resistência aos herbicidas é a leiteira (Euphorbia heterophylla). Este trabalho foi planejado para avaliar a distribuição geográfica de E. heterophylla resistente aos herbicidas nos estados do Paraná e Rio Grande do Sul e para obter dados que identificassem os principais fatores de manejo associados à seleção de biótipos resistentes na área. Sementes de E. heterophylla de 148 locais foram coletadas nos anos de 2001 e 2002. Em cada local, os agricultores informaram os procedimentos relativos a controle de plantas daninhas, sistema de preparo do solo, rotação de culturas e colheita. Este trabalho demonstrou que biótipos resistentes aos herbicidas inibidores da ALS estão amplamente distribuidos na região amostrada. A disseminação de sementes de plantas resistentes não é a provável causa da ampla distribuição da resistência. $O$ principal fator responsável pela seleção de plantas resistentes na espécie E. heterophylla foi a elevada utilização de herbicidas inibidores de ALS nos anos que antecederam a coleta. Foram apresentadas evidências indiretas que demonstram a necessidade de educar os legisladores $e$ agricultores com respeito à importância da mistura de herbicidas na prevenção da resistência aos herbicidas.
\end{abstract}

Palavras-chave: imazethapyr, leiteira, mistura de herbicidas.

\footnotetext{
Recebido para publicação em 13.4.2004 e na forma revisada em 10.9.2004.

2 Eng. Agr., Professores, Departamento de Plantas de Lavoura da Fauldade de Agronomia da Universidade Federal do Rio Grande do Sul -UFRGS, Caixa Postal 15100, 90001-970 Porto Alegre-RS, Bolsistas do CNPq, <ribas.vidal@ufrgs.br>; ${ }^{3}$ Eng.-Agr., bolsista recém-doutor do CNPq; ${ }^{4}$ Eng.-Agr., M.S., estudante do Programa de Pós-Graduaçao em Fitotecnia da UFRGS. ${ }^{5}$ Eng.Agr., Dr., professor do Centro Federal de Educação Tecnológica, Pato Branco-PR.
} 


\section{INTRODUCTION}

Wild poinsettia is a very common weed in the Brazilian soybean growing areas. This weed is native to South America (Kissmann $\&$ Groth, 1992) and has a severe impact on soybean yield. Each wild poinsettia plant $\mathrm{m}^{-2}$, when competing during the whole season with soybean, reduces grain yield by 0.7 to $3.0 \%$ (Chemale \& Fleck, 1982; Holm et al., 1997; Voll et al., 2002). Soybean must be wild poinsettia-free from 17 to 44 days after crop emergence to avoid yield losses (Meschede et al., 2002).

Soybean is planted in over 18 millions ha in Brazil. The oldest soybean growing areas are located in the southern part of the country, which account for about $50 \%$ of the grain produced. In this region, Paraná and Rio Grande do Sul states have the highest soybean acreage, with production concentrated in the western and northern regions of each state, respectively.

Since 1986, wild poinsettia control in soybeans has been achieved mainly by herbicides which inhibit the acetolactate synthase (ALS) enzyme. During this period, the adoption of the no-till system has increased in the region. Likewise, the increase in the soybean monocrop has been steadily during this decade. We hypothesize these management practices are associated to the selection of herbicide resistant biotypes.

In fact, several reports indicated the appearance of wild poinsettia biotypes resistant to ALS inhibitors in southern Brazil (Gazziero et al., 1998; Vidal \& Merotto Jr., 1999). ALS resistance in wild poinsettia is a dominant trait and nuclear encoded (Vargas et al., 2001). ALS enzyme studies performed on a limited number of wild poinsettia biotypes indicate an altered target site as the cause of resistance (Vargas et al., 2001; Oliveira et al., 2002). The molecular basis for resistance to ALS inhibiting herbicides is well established in other plant species and is attributed to aminoacid substitutions in one of five regions of the ALS enzyme, which in turn occurs due to a single base-mutation on the respective regions of the ALS gene (Devine \& Shukla, 2000).

Planta Daninha, Viçosa-MG, v. 22, n. 3, p. 403-410, 2004
There is controversy concerning the distribution of ALS resistant wild poinsettia in Brazil. Heap (2003) reports the occurrence of resistant biotypes to be limited to less than 10 places, whereas Cerqueira et al. (2002) reported the occurrence of resistant biotypes to be over 50 counties in southern Brazil. No surveys of weed resistance in Brazil are found in the literature; however several surveys document the status of weed resistance in other parts of the world (Bourgeois \& Morrison, 1997; Bourgeois et al., 1997; Beckie et al.., 1999; Légere et al., 2000; Llewellyn \& Powles, 2001).

The objectives of this study were to determine the distribution of ALS-resistant populations of wild poinsettia in two states in southern Brazil and to obtain data to determine the major contributing management causes for weed resistance selection in the area.

\section{MATERIALS AND METHODS}

E. heterophylla flowers between January and March, in southern Brazil, and produces mature seeds from February to April. Wild poinsettia seed is disseminated through explosive dehiscence soon after maturity almost one month before soybean harvest. For this survey, immature wild poinsettia fruits were collected in February-April 2001 and 2002 from plants occurring in soybean growing areas located in Rio Grande do Sul and Paraná states, respectively.

Fields sampled were suspected of having ALS resistance and had a minimum of 50 surviving wild poinsettia plants $\mathrm{m}^{-2}$. A total of 148 seed samples were collected from soybean fields located in 24 and 42 counties in Rio Grande do Sul and Paraná, respectively (Figure 1, Table 1). The area sampled for E. heterophylla seeds totaled almost 13,000 ha, with 4,100 ha located in Paraná state and about 8,800 ha in Rio Grande do Sul (Table 1). In Paraná, the majority of samples were collected from small weed patches, whereas in Rio Grande do Sul, the majority of samples were collected from weed patches bigger than 50 ha (Table 1). For both states, most counties had only one or two samples collected (Table 3). 


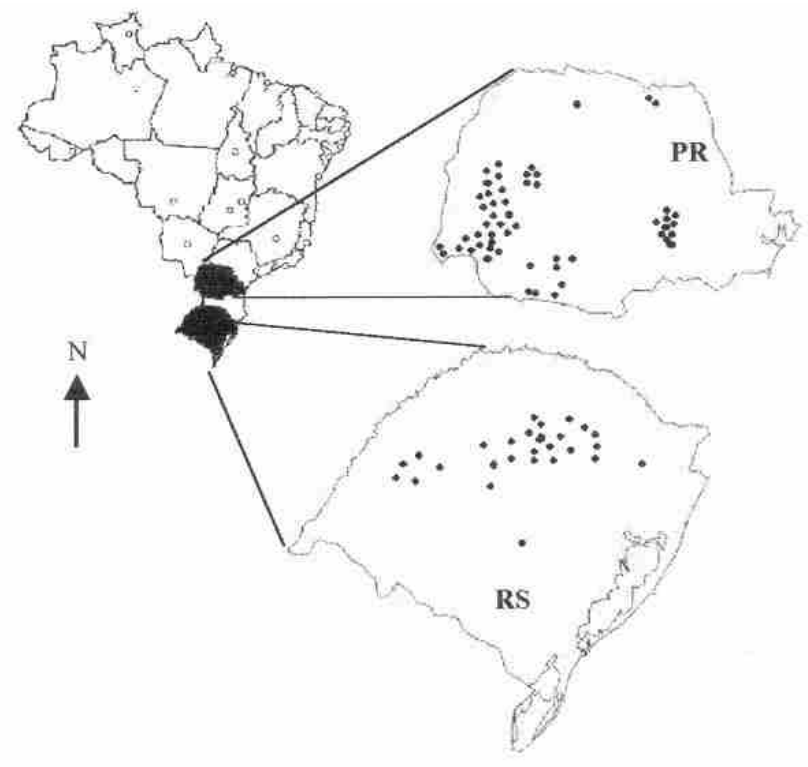

Figure 1 - Map of Brazil, with blown up maps of Paraná (PR) and Rio Grande do Sul (RS) states. Each dot on state maps represents approximate location of two sampling sites of Euphorbia heterophylla seeds.

Table 1 - Number of sites sampled for Euphorbia heterophylla seeds, counties, and total area with suspected ALS resistance, organized by state

\begin{tabular}{|l|c|c|c|}
\hline \multirow{2}{*}{} & \multicolumn{2}{|c|}{ State } & \multirow{2}{*}{ Total } \\
\cline { 2 - 3 } & Paraná & $\begin{array}{c}\text { Rio Grande } \\
\text { do Sul }\end{array}$ & \\
\hline Number of samples & 103 & 45 & 148 \\
\hline Number of counties & 42 & 24 & 66 \\
\hline Area sampled (ha) & 4.100 & 8.760 & 12.860 \\
\hline
\end{tabular}

Table 2 - Sites (\%) sampled for Euphorbia heterophylla seeds from plants suspected of resistance to herbicides, organized by size distribution of the area, and by state

\begin{tabular}{|c|c|c|c|}
\hline \multirow{2}{*}{$\begin{array}{c}\text { Size } \\
\text { distribution } \\
\text { (ha) }\end{array}$} & \multicolumn{2}{|c|}{ State } & \multirow{2}{*}{ Average } \\
\cline { 2 - 4 } & Paraná & $\begin{array}{c}\text { Rio Grande do } \\
\text { Sul }\end{array}$ & \\
\hline$<10$ & 32 & 20 & 26 \\
\hline $11-20$ & 21 & 9 & 15 \\
\hline $21-30$ & 9 & 4 & 6 \\
\hline $31-40$ & 7 & 4 & 5 \\
\hline $41-50$ & 9 & 7 & 8 \\
\hline $51-100$ & 9 & 17 & 13 \\
\hline $101-200$ & 9 & 14 & 12 \\
\hline$>200$ & 4 & 24 & 14 \\
\hline
\end{tabular}

Table 3 - Number of counties, by state, according to sampling frequency per county assessed for Euphorbia heterophylla seeds from plants suspected of resistance to herbicides.

\begin{tabular}{|c|c|c|c|}
\hline \multirow{2}{*}{$\begin{array}{c}\text { Sites per } \\
\text { county }\end{array}$} & \multicolumn{2}{|c|}{ State } & \multirow{2}{*}{ Average } \\
\cline { 2 - 4 } & Paraná & $\begin{array}{c}\text { Rio Grande do } \\
\text { Sul }\end{array}$ & \\
\hline 1 & 16 & 10 & 13 \\
\hline 2 & 13 & 10 & 11 \\
\hline 3 & 6 & 2 & 4 \\
\hline 4 & 1 & 1 & 1 \\
\hline 5 or + & 6 & 1 & 3 \\
\hline
\end{tabular}

Fruit were sampled from at least 20 plants along a W shaped path. At least 1000 fruits were collected on surviving wild poinsettia plants located in each soybean field. Wild poinsettia fruits were stored at room temperature inside paper bags, and when completely ripe, the seeds were stored at room temperature. After fruit/seed collection, farmers were asked a series of management questions, presented on Table 4. Questionnaire answers were converted to percentage in relation to the total of respondents per state, and averaged for both states.

In August of each year, about 15 wild poinsettia seeds were planted in $300 \mathrm{~cm}^{-3}$ pots. Seeds from a known susceptible population were planted as a control. Each biotype was planted with two replicates. The potting mix consisted of 33\% soil, 33\% sand and 33\% peat. When most plants were at the four-leaf stage, imazethapyr was sprayed at $200 \mathrm{~g} \mathrm{ha}^{-1}$, with a nonil-phenol adjuvant $(0.2 \% \mathrm{v} / \mathrm{v})$ using a hand-held sprayer delivering a total (two passes) of $220 \mathrm{~L} \mathrm{ha}^{-1}$ at $200 \mathrm{kPa}$. This herbicide application rate was twice the maximum labeled rate. Only populations with plants surviving both replicates were documented as resistant.

\section{RESULTS AND DISCUSSION}

Weed control information. Seed collected from all sites demonstrated resistance to the ALS inhibitor tested, with very few susceptible plants in each biotype. As the sampled region was randomly distributed around the soybean growing areas in Paraná and Rio Grande do Sul state, respectively (Figure 1), these results

Planta Daninha, Viçosa-MG, v. 22, n. 3, p. 403-410, 2004 
suggests $E$. heterophylla ALS-resistant biotypes are distributed throughout the soybean area of southern Brazil.

For both states, the majority of the samples $(71 \%)$ were collected in areas where the farmer suspected weed resistance for two or more years (Table 5). This is not surprising because ALS-inhibiting herbicides have been used in the region for at least 15 years and a rapid increase in the magnitude of herbicideresistance problems is expected in areas where few alternative herbicide mode of action are available (Heap \& Lebaron, 2001).

The predominant tillage system in the sampled area was the no-till. Overall for both states, $68 \%$ of the farms were using no-tillage for 5 or more years (Table 6). A no-tillage system makes farmers more dependent on herbicides and less likely to adopt other weed control strategies, thus increasing the selection pressure of the chemicals used for the vegetation management (Owen, 2001).

Table 6 - Sites (5), by state, according to tillage system in areas sampled for Euphorbia heterophylla resistance to herbicides, and number of years in the no-tillage system

\begin{tabular}{|c|c|c|c|}
\hline \multirow{2}{*}{ Tillage system } & \multicolumn{2}{|c|}{ State } & \multirow{2}{*}{ Average } \\
\cline { 2 - 3 } & Paraná & $\begin{array}{c}\text { Rio Grande } \\
\text { do Sul }\end{array}$ & \\
\hline No-tillage & 100 & 91 & 95 \\
\hline Conventional & 0 & 9 & 4 \\
\hline Years in no-till & & & \\
\hline$<4$ years & 24 & 10 & 17 \\
\hline $5-8$ years & 55 & 48 & 51 \\
\hline$>8$ years & 21 & 42 & 31 \\
\hline
\end{tabular}

Table 4 - Questionnaire assessed for each Euphorbia heterophylla population sampled

\begin{tabular}{|c|c|}
\hline \multicolumn{2}{|l|}{ Property information } \\
\hline Property name: & Phone number: \\
\hline Farmer name: $\quad$ County: & State: \\
\hline Soil Preparation system (no-till/conventional): & Number of years in this system: \\
\hline \multicolumn{2}{|l|}{ Weed control information } \\
\hline Number of years suspected weed resistance to herbicides: & Size of problem area: \\
\hline Last herbicide used: & Surfactants: \\
\hline Other herbicides used in the season: & Rate: $\quad$ Surfactants: \\
\hline Herbicides used last winter: & Herbicides used last summer: \\
\hline Herbicides used 2 winters ago: & Herbicides used 2 summers ago: \\
\hline Herbicides used 3 winters ago: & Herbicides used 3 summers ago: \\
\hline \multicolumn{2}{|l|}{ Crop rotation information } \\
\hline Crop planted last winter: & Crop planted last summer: \\
\hline Crop planted 1 winter ago: & Crop planted 2 summer ago: \\
\hline Crop planted 2 winters ago: & Crop planted 3 summers ago: \\
\hline \multicolumn{2}{|l|}{ Harvesting information } \\
\hline Harvest for neighbors (yes/no): & Neighbors have weed resistance (yes/no): \\
\hline
\end{tabular}

Table 5 - Sites (\%), by state, according to the time of suspecting resistance of Euphorbia heterophylla to ALS herbicides.

\begin{tabular}{|c|c|c|c|}
\hline \multirow{2}{*}{ Time } & \multicolumn{2}{|c|}{ State } & \multirow{2}{*}{ Average } \\
\hline & Paraná & Rio Grande do Sul & \\
\hline The year of sampling & 15 & 11 & 13 \\
\hline One year before sampling & 13 & 17 & 15 \\
\hline Two years before sampling & 33 & 26 & 29 \\
\hline Three years before sampling & 39 & 46 & 42 \\
\hline
\end{tabular}


The mechanism of action of the herbicides used on the seed sampling year was mainly (68\%) ALS inhibitors. For both years before the time of E. heterophylla sampling, ALS inhibitors were also the predominant mode of action used (Table 7). Several factors modify the rate of evolution of herbicide resistance in a region; however the most important factors controlling this phenomenon are the intensity of herbicide use and the initial frequency of the herbicide resistant gene (Maxwell \& Mortlmer, 1994; Winkler et al., 2002). The initial frequency of ALS-resistant cells in Nicotiana tabacum cell culture was $10^{-8}$ (Harms \& Dimaio, 1991) and in Gossipium hirsutum cell culture was $10^{-7}$ (Rajasekaran et al., 1996), implying that in a few generations of the constant use of an ALS-inhibiting resistant biotypes would dominate a weed community (Maxwell \& Mortlmer, 1994). However, recent research indicates that in Lolium rigidum populations never sprayed with ALS-inhibiting herbicides, the initial frequency of individuals resistant to this group of herbicides can be as high as $10^{-4}$ (Preston \& Powles, 2002), explaining the appearance of resistant biotypes with only 3 years of constant use of herbicides from this group (Powles et al., 1997).

There was a trend of increased use of PROTOX inhibitors with time. In fact, only $5 \%$ of sites used herbicides with this mode of action two years before seed sampling and 17\% at the time of sampling. Likewise, for both states, the use of mixtures of herbicides for $E$. heterophylla control followed an increasing trend from $5 \%$ of sites using compounds with several mechanisms of action two years before seed sampling to $13 \%$ at the time of sampling (Table 7).

In the state of Rio Grande do Sul, there was a trend of higher use of herbicide mixture from different mechanisms of action, when compared to Paraná state. This may be, in part, a consequence of severe law enforcement in Paraná. In Brazil, against all biological and agronomical logics, the pesticide law forbids the mixture of herbicides and the state of Paraná is known to strongly enforce this law. We speculate the lack of mixture of herbicide from different mechanisms of action may have severe negative consequences for the selection of herbicide resistant biotypes. In fact, Trezzi et al. (2004) documented the first case of multiple herbicide resistance in Brazil, in Paraná state, in the species Euphorbia heterophylla.

The trend of increased use of herbicides from alternative mechanism of action, or increased use of herbicide mixture, for $E$. heterophylla control is in agreement with the results from Table 5, that demonstrated the farmers suspected ALS resistant biotypes to be present on the area for a couple of years before sampling and probably were advised to adopt alternative herbicides to control the ALS-resistant biotypes.

Table 7 - Herbicide use (\%), organized by mechanism of action and state, in relation to the time of sampling for seeds for Euphorbia heterophylla resistance to ALS herbicides

\begin{tabular}{|c|c|c|c|c|}
\hline \multirow{2}{*}{ Time of seed sampling } & \multirow{2}{*}{ MoA* } & \multicolumn{2}{|c|}{ State } & \multirow{2}{*}{ Average } \\
\hline & & Paraná & Rio Grande do Sul & \\
\hline \multirow{3}{*}{ Year of seed sampling } & ALS & 78 & 58 & 68 \\
\hline & PROTOX & 15 & 20 & 17 \\
\hline & MIX & 5 & 22 & 13 \\
\hline \multirow{3}{*}{ One year before } & ALS & 61 & 65 & 63 \\
\hline & PROTOX & 5 & 18 & 11 \\
\hline & MIX & 8 & 10 & 9 \\
\hline \multirow{3}{*}{ Two years before } & ALS & 88 & 82 & 85 \\
\hline & PROTOX & 5 & 6 & 5 \\
\hline & MIX & 4 & 6 & 5 \\
\hline
\end{tabular}

$* \mathrm{MoA}=$ mechanism of action; ALS $=$ herbicides inhibitors of the acetolactate synthase enzyme; PROTOX = inhibitors of protoporphyrinogen oxidase enzyme; MIX = mixture of herbicides from these two MoA. 
Another supporting evidence that the farmers encountered herbicide resistance prior the sampling date is the trend of increased need of a second herbicide for $E$. heterophylla control, starting from $59 \%$ of the sites two years before the sampling up to $71 \%$ of the sites at the sampling year (Table 8). Unfortunately, overall for both states, 48 to $62 \%$ of the second herbicide chosen to complement the weed control was ALS inhibitors (Table 8). This result suggests the need to improve farmer education on herbicide mode of action and its rotation as strategy to minimize the selection of herbicide resistant plants.

Crop rotation and equipment information. On average, the majority of the sampled sites were cultivated with soybean crop on the assessment year or on the years preceding it. There was a trend of increased use of crop rotation in Rio Grande do Sul than in Paraná (Table 9). The weed communities that have developed in soybean monocrop tend to have a large seedbank of some species due to limited options of alternative herbicides available for their control (Owen, 2001). With a large weed seed bank, higher weed densities are expected in these areas, which predispose these sites to an increased probability of selecting for a resistant biotype (Jasieniuk et al., 1996; Vidal \& Fleck, 1997).

For both states, the majority of the farmers $(81 \%)$ where the samples were collected own the combine used to harvest the crop (Table 10). Of these, only 34\% harvest for neighbors (Table 10). On average, $63 \%$ of the

Table 8 - Use (\%) of a second herbicide in the season, by state, in relation to the time of sampling for seeds for Euphorbia heterophylla resistance to ALS herbicides

\begin{tabular}{|c|c|c|c|}
\hline \multirow{2}{*}{ Time of seed sampling } & \multicolumn{2}{|c|}{ State } & \multirow{2}{*}{ Average } \\
\hline & Paraná & Rio Grande do Sul & \\
\hline Year of seed sampling & $\begin{array}{c}82 \\
(63) \\
\end{array}$ & $\begin{array}{c}60 \\
(34) \\
\end{array}$ & $\begin{array}{c}71 \\
(48) \\
\end{array}$ \\
\hline One year before & $\begin{array}{c}67 \\
(73) \\
\end{array}$ & $\begin{array}{c}65 \\
(52) \\
\end{array}$ & $\begin{array}{c}66 \\
(62) \\
\end{array}$ \\
\hline Two years before & $\begin{array}{c}63 \\
(62)\end{array}$ & $\begin{array}{c}55 \\
(36)\end{array}$ & $\begin{array}{c}59 \\
(49)\end{array}$ \\
\hline
\end{tabular}

* Number in parenthesis represents percentage of use of herbicides inhibitors of the acetolactate synthase enzyme, within the result above it.

Table 9 - Sites (\%) with soybean crop, by state, according to the time of sampling for seeds of Euphorbia heterophylla ALS resistant

\begin{tabular}{|l|c|c|c|}
\hline \multirow{2}{*}{ Time } & \multicolumn{2}{|c|}{ State } & \multirow{2}{*}{ Average } \\
\cline { 2 - 4 } & Paraná & Rio Grande do Sul & \\
\hline The year of sampling & 91 & 64 & 77 \\
One year before sampling & 89 & 77 & 83 \\
\hline Two years before sampling & 89 & 74 & 81 \\
\hline
\end{tabular}

Table 10 - Sites (\%), by state, where farmers own combine or harvest for neighbors

\begin{tabular}{|c|c|c|c|}
\hline \multirow{2}{*}{ Combine ownership } & \multicolumn{2}{|c|}{ State } & \multirow{2}{*}{ Average } \\
\cline { 2 - 4 } & Paraná & Rio Grande do Sul & 81 \\
\hline Owns combine: Yes & 72 & 91 & 19 \\
\hline No & 28 & 9 & \\
\hline Combine use & & & 34 \\
Harvest for neighbors: Yes & 60 & 73 & 66 \\
\hline
\end{tabular}


neighbors from farmers that harvest for them have resistant $E$. heterophylla, however this result is not significantly different from the ones without resistance (Table 11). This result suggests the use of shared combine is not responsible for the spread of weed resistance. In fact, by the time of soybean harvest, seeds on E. heterophylla plants have dehisced (Kissmann \& Groth, 1992) and none are expected to be harvested by the combine.

This study demonstrates that ALS resistant $E$. heterophylla biotypes are widely distributed in southern Brazil. The analysis of questionnaire data suggests the dissemination of seeds from resistant plants is unlikely to be the explanation for the widespread distribution of resistance. The primary factor contributing to the selection of the ALS resistant biotype probably was the high use of ALS-inhibiting herbicides in years preceding our sampling. The results suggest the need to educate farmers on the importance of rotation of herbicides of different mode of action and the importance of crop rotation to prevent selecting resistant biotypes. Indirect evidence is presented demonstrating the need to educate legislators about the importance of herbicide mixtures as a strategy to prevent herbicide resistance. More studies should be done on integrated weed management in the no-tillage systems to minimize its limitation on weed control methods.

\section{AKNOWLEGMENTS}

To CNPQ and FAPERGS, for financing this study. To Drs. J.D. Doll and K. McNabb, for suggestions that improved this paper.

\section{LITERATURE CITED}

BECKIE, H. J. et al. Nature, occurrence, and cost of herbicide-resistant wild oat (Avena fatua) in small-grain production areas. Weed Technol., v. 13, n. 3, p. 612-625, 1999.

BOURGEOIS, L.; MORRISON, L. N. A survey of ACCase inhibitor resistant wild oat in a high risk township in Manitoba. Can. J. Plant Sci., v. 77, n. 4, p. 703-708, 1997.

BOURGEOIS, L.; MORRISON, L. N.; KELNER, D. Field and producer survey of ACCase resistant wild oat in Manitoba. Can. J. Plant Sci., v. 77, n. 4, p. 709-7I5, 1997.
CERQUEIRA, M. S. et al. Quadro atuaIizado da situação das wrs no sul do Brasil e alternativas Basf para seu manejo. In: CONGRESSO BRASILEIRO DA CIÊNCIA DAS PLANTAS DANINHAS, 23., 2002, Gramado-RS. Resumos... Pelotas: SBCPD, 2002. p. 205.

CHEMALE, V. M.; FLECK, N. G. Avaliação de cultivares de soja (Glycine max (L.) Merrill) em competição com Euphorbia heterophylla L. sob três densidades e dois períodos de ocorrência. Planta Daninha, v. 5, p. 36-45, 1982.

DEVINE, M. D.; SHUKLA, A. Altered target sites as a mechanism of herbicide resistance. Crop Protec., v. 19, p. $881-889,2000$.

GAZZIERO, D. L. P. et al. Resistência de amendoim-bravo aos herbicidas inibidores da enzima ALS. Planta Daninha, v. 16 , n. 2, p. 117-125,1998.

HARMS, C. T.; DIMAIO J. J. Primisulfuron herbicideresistant tobacco cell-lines- Application of fluctuation test design to in vitro mutant selection with plant cells. J. Plant Physiol., v. 137, n. 5, p. 513-519, 1991.

HEAP, I. International survey of herbicide-resistant weeds. Online. Internet. Available at: <http:// www.weedscience.com>. Current as of june/23/2003.

HEAP, I.; LEBARON, H. Introduction and overview of resistance. In: POWLES, S. B.; SHANER, D. L. (Eds.) Herbicide resistance and world grains. Boca Raton: $\mathrm{CRC}$ Press, 2001. p. 1-22.

HOLM, L. et al. World weeds: natural histories and distribution. New York: Wiley, 1997. 1129 p.

JASIENIUK, M.; BRÜLÉ-BABEL, A. L.; MORRISON, I. $\mathrm{N}$. The evolution and genetics of herbicide resistance in weeds. Weed Sci., v. 44, n. 2, p. 176-193, 1996.

KISSMANN, K. G.; GROTH, D. Plantas infestantes e nocivas. São Paulo: BASF, 1992. v. 2. p. 647-653.

LEGÉRE, A. et al. Survey of management practices affecting the occurrence of wild oat (Avena fatua) resistance to acetyl-CoA carboxilase inhibitors. Weed Technol., v. 14, n. 2, p. 366-376, 2000.

LLEWELLYN, L. S.; POWLES, S. B. High levels of herbicide resistance in rigid ryegrass (Lolium rigidum) in the wheat belt of western Australia. Weed Technol., v. 15, n. 2, p. $242-248,2001$.

MAXWELL, B. D.; MORTIMER, A. M. Selection for herbicide resistance. In: POWLES, S. B.; HOLTUM, J. A. M. (Eds.). Herbicide resistance in plants: biology, and biochemistry. Boca Raton: Lewis, 1994. p. 1-25.

Planta Daninha, Viçosa-MG, v. 22, n. 3, p. 403-410, 2004 
MESCHEDE, D. K. et al. Período crítico de interferência de Euphorbia heterophylla na cultura da soja sob baixa densidade de semeadura. PIanta Daninha, v. 20, n. 3, p. 381-387, 2002.

OLIVEIRA, M. F. et al. Atividade da acetolactato sintase de plantas de milho e de amendoim-bravo (Euphorbia heterophylla) resistentes e suscetíveis ao imazaquin. Planta Daninha, v. 20, n. 1, p. 77-82, 2002.

OWEN, M. D. K. World maize/soybean herbicide resistance. In: POWLES, S. B.; SHANER, D. L. Herbicide resistance and world grains. Boca Raton: CRC Press, 2001. p. 101-164.

POWLES, S. B. et al. Herbicide resistance: impact and management. Adv. Agron., v. 58, n. 1, p. 57-93, 1997.

PRESTON, C.; POWLES, S. B. Evolution of herbicide resistance in weeds: initial frequency of target site-based resistance to acetolactate synthase-inhibiting herbicides in Lolium rigidum. Heredity, v. 88, n. 1, p. 8-13, 2002.

RAJASEKARAN, K.; GRULA, J. W.; ANDERSON, D. M. Selection and characterization of mutant cotton (Gossypium hirsutum L) celI lines resistant to sulfonylurea and imidazolinone herbicides. Plant Sci., v. 119, n. 1-2, p. 115124, 1996.
TREZZI, M. M. et al. Multiple resistance to acetolactate synthase and protoporphyrinogen oxidase inhibitors in Euphorbia heterophylla biotypes. Journal of Environmental Sciences and Health. 2004. (In press)

VARGAS, L.; BORÉM, A.; SILVA, A. A. Herança da resistência aos herbicidas inibidores da ALS em biótipos da planta daninha Euphorbia heterophylla. Planta Daninha, v. 19, n. 3, p. 331-336, 2001.

VIDAL, R. A.; FLECK, N. G. Análise do risco da ocorrência de biótipos de plantas daninhas resistentes aos herbicidas.

Planta Daninha, v. 15, n. 12, p. 152-161, 1997.

VIDAL, R. A.; MEROTTO Jr., A. Resistência de amendoim-bravo aos herbicidas inibidores da enzima acetolactato sintase. Planta Daninha, v. 17, n. 3, p. 367373, 1999.

VOLL, E. et al. Competição relativa de espécies de plantas daninhas com dois cultivares de soja. Planta Daninha, v. 20 , n. 1, p. 17-24, 2002.

WINKLER, L. M.; VIDAL, R. A.; BARBOSA NETO, J. F. Aspectos genéticos envolvidos na resistência de plantas daninhas aos herbicidas. Plantio Direto, v. 70, p. 21-24, 2002. 